\title{
Reactivity of sulfonylbutadienes. Synthesis of Ginsenol analogues
}

\author{
David Díez, ${ }^{\text {a* }}$ Sonia G. Sanfeliciano, ${ }^{\text {a }}$ Javier Peña, ${ }^{a}$ M. Fe Flores, ${ }^{\text {a }}$ Pilar García, Narciso M.

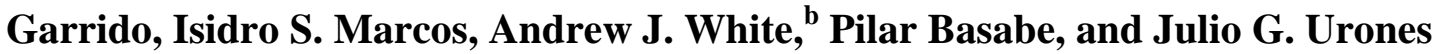 \\ ${ }^{a}$ Departamento de Química Orgánica, Facultad de Ciencias Químicas, Universidad de \\ Salamanca. Plaza de los Caídos 1-5, 37008 Salamanca. Spain \\ ${ }^{b}$ Department of Chemistry, Imperial College of Science, Technology and Medicine, London SW7 \\ 2AZ, UK \\ E-mail:ddm@usal.es
}
This manuscript is dedicated to Professor Julio Álvarez Builla on occasion of his $65^{\text {th }}$ birthday

\begin{abstract}
The reactivity of sulfonylbutadienes has been studied with enamines and the obtained products used as starting materials for the synthesis of Ginsenol analogues.
\end{abstract}

Keywords: Sulfonylbutadienes, Ginsenol, Panax ginseng, bicycles [3.3.1]

\section{Introduction}

Ginsenol is a tricyclic sesquiterpene with a tertiary hydroxyl group that has been isolated from the roots of Panax ginseng bre ${ }^{1}$, figure 1. Its carbon framework appears in a large number of natural diterpenes and alkaloids ${ }^{2}$. Among Ginsenol biological properties include its antifungal activity in vitro against Botrytis cinerea ${ }^{3}$, pathogens of many crops and lettuce, tomatoes and grapes, producing diseases manifested by the appearance of spots on the leaves and the coating of the plant with a powdery gray mold, hence the name ${ }^{4}$.
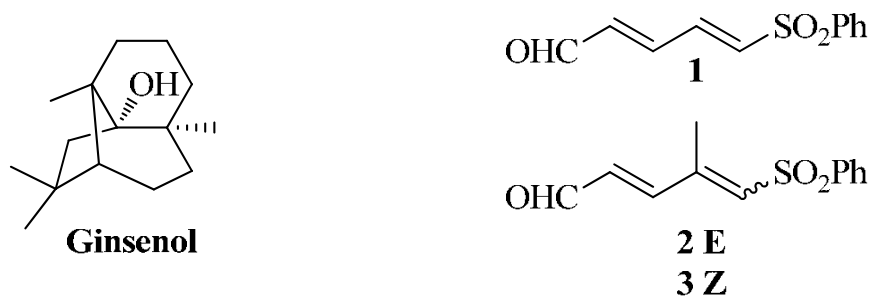

Figure 1. Ginsenol and sulfonyldienes. 
In our group, we have been interested in the reactivity of sulfonylbutadienes for many years in order to obtain biologically active compounds. ${ }^{5}$ Having studied the synthesis of bicyclic[3.3.1] systems ${ }^{6}$, we decided to use our knowledge to apply it to the synthesis of systems like Ginsenol. In this sense we study the reactivity of dienylsulfones with enamines derived from cyclohexanone to obtain bicyclic[3.3.1] systems and secondly, its application for the synthesis of Ginsenol analogues.

\section{Results and Discussion}

When a mixture of compounds $2 \mathbf{E}$ and $\mathbf{3 Z}(85 / 15)$, previously obtained by our group, was treated with enamine 4-(1-cyclohexenyl)morpholine a mixture of compounds $\mathbf{4 a}$ and $\mathbf{4 b}$ were obtained in a moderate yield of $36 \%$. Scheme 1 .
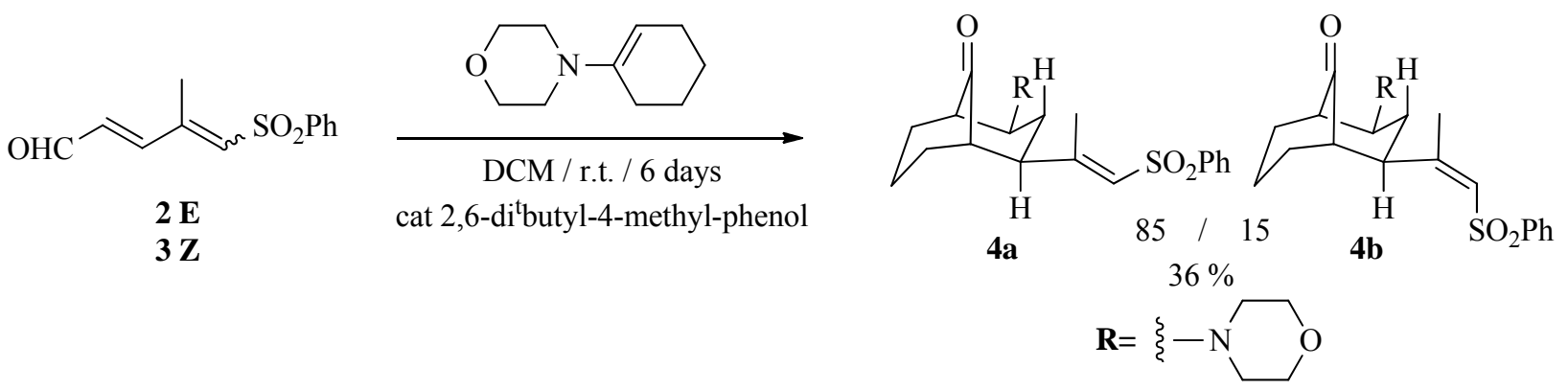

Scheme 1. Reaction of sulfonylbutadienes with 4-(1-cyclohexenyl)morpholine.

The structure of compound 4a was established unequivocally by mono and bidimensional NMR studies and double irradiation experiments. ${ }^{13} \mathrm{C}-\mathrm{NMR}$ spectrum of compound 4 a shows the signal corresponding to $\mathrm{C}-7(16.3 \mathrm{ppm})$, similar to analogue compounds described in literature with chair-boat conformation ${ }^{7}$. Indeed, signal corresponding to C-7 appears at a higher shift than $20 \mathrm{ppm}$ in double-chair conformations. Moreover, differences at ${ }^{1} \mathrm{H}-\mathrm{NMR}$ spectrum shifts for hydrogens at position 3 are also remarkable. In this compound, due to the carbonyl anisotropic effect, the axial hydrogen at $\mathrm{C}-3$ (H-3 $\beta)$ appears at $1.25 \mathrm{ppm}$ as a quartet of coupling constants $12.6 \mathrm{~Hz}$, and the signal of the equatorial hydrogen at $1.70 \mathrm{ppm}$ as a double triplet of constants 12.6 and $2.0 \mathrm{~Hz}$. The hydrogen at $2.95 \mathrm{ppm}$, which appears as a double triplet of constants 12.6 and $2.0 \mathrm{~Hz}$, corroborates the chair-boat conformation and the equatorial position of the morpholine group, Figure 2.

The spectroscopic properties of $\mathbf{4 b}$ were obtained from a fraction mixture of $\mathbf{4 a} / \mathbf{4 b}$ very enriched in $\mathbf{4 b}$. The presence of a quartet for hydrogen at C-3 shows the same conformation (1.25 ppm, q, $J=12.6 \mathrm{~Hz}$ ) and substitution than 4a. The methyl on the double bond (Me-C-1') shift, both at the ${ }^{1} \mathrm{H}-\mathrm{NMR}$ and ${ }^{13} \mathrm{C}-\mathrm{NMR}$ spectra, shows that $\mathbf{4 b}$ is the same compound than $\mathbf{4 a}$ but with a Z-geometry at the double bond (Figure 2). 


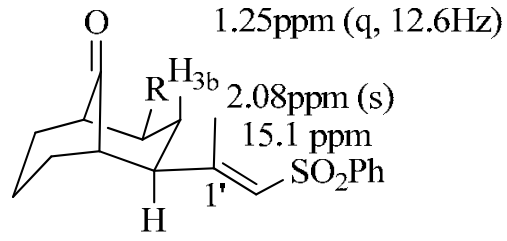

4a

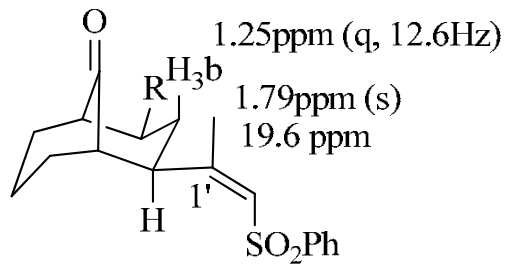

4b

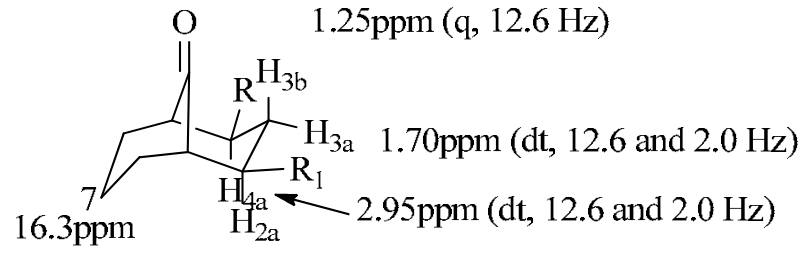

4a
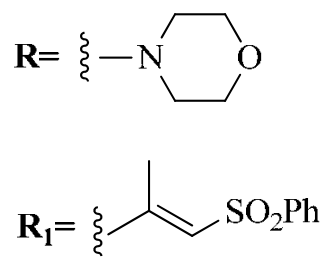

Figure 2. Spectroscopic data for compounds $\mathbf{4 a}$ and $\mathbf{4 b .}$

Studies made in these systems by other researching groups show that the 2,4-diaxial interaction at the chair-chair conformation of a bulky group (like morpholine) at position 2-exo, forces the bicyclo[3.3.1]nonane (hybridization $\mathrm{sp}_{2}$ at C-9) to adopt the chair-boat conformation. ${ }^{8}$ This fact is also observed at bicyclo[3.3.1]nonan-9-ones 2-exo and 4-exo dicarboxylic ${ }^{9}$ or 2,4disubstituted bicyclo[3.3.1]nonan-9-one. ${ }^{10}$

This bicyclo[3.3.1]nonan-9-one 4a was possible to be crystallized, consequently X-ray diffraction experiments let corroborate the structure derived from resonance, see Figure 3.

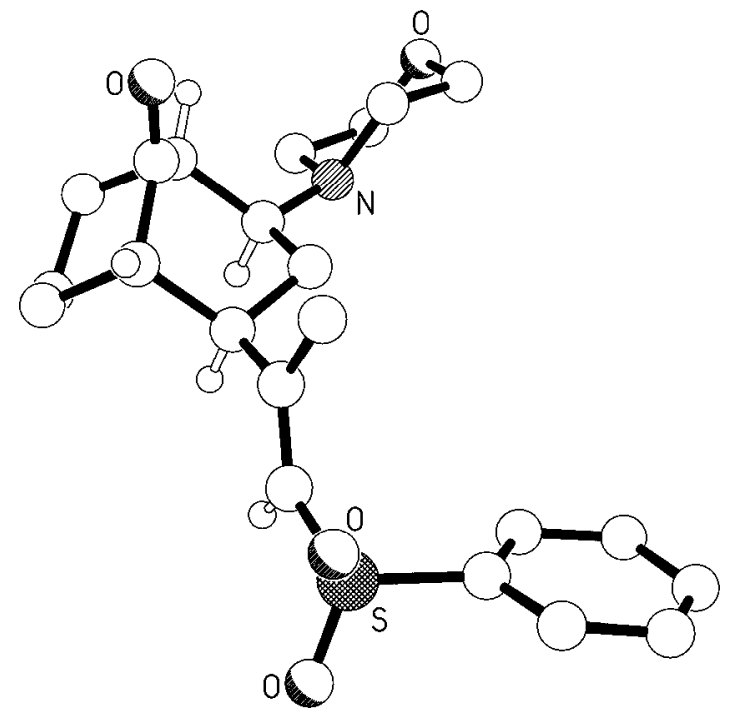

Figure 3. The molecular structure of one (B) of the three crystallographically independent molecules present in the crystals of $\mathbf{4 b}$. See experimental part and supporting information. 
Next, the reactivity of sulfonylbutadiene 1 was studied with different enamines such as 4-(1cyclohexenyl)morpholine, 4-(1-cyclopentenyl)morpholine and 1-cyclohexen-1-enyl-pyrrolidine.

\section{Reactivity with 4-(1-cyclohexenyl)morpholine}

The different conditions scoped for the reaction between 1 and 4-(1-cyclohexenyl)morpholine are shown in Table1.

Table 1. Treatment of 1 with 4-(1-cyclohexenyl)morpholine to obtain the bicyclic system 5.
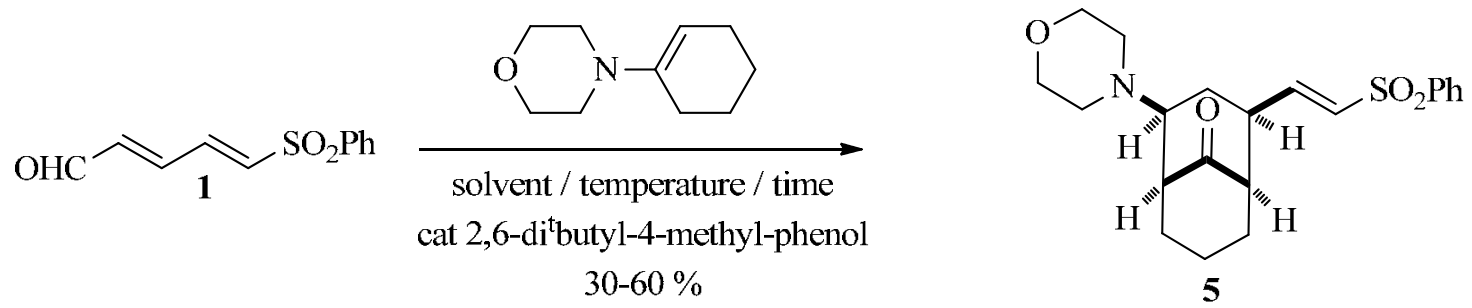

\begin{tabular}{cccccc}
\hline Entry & $1(\mathrm{mmol})^{\mathrm{a}}$ & Solvent & $\mathrm{T}\left({ }^{\circ} \mathrm{C}\right)$ & $\mathrm{t}$ & $5(\%)$ \\
\hline 1 & 0.61 & 1,4 -Dioxane & 20 & 5 days & 38 \\
2 & 0.07 & DCM & 20 & $12 \mathrm{~h}$ & 50 \\
3 & 0.20 & DCM & 20 & 5 days & 60 \\
4 & 1.63 & DCM & 20 & $12 \mathrm{~h}$ & 45 \\
\hline
\end{tabular}

${ }^{\mathrm{a}}$ All the experiments were carried out using 5 equivalents of enamine per each equivalent of $\mathbf{1}$.

The structure of 5 was established by comparison of the NMR spectra of $\mathbf{4 a}$ and $\mathbf{4 b}$, as well as those bicyclo[3.3.3]nonanes synthesized previously in our laboratory. ${ }^{6}$ The ${ }^{1} \mathrm{H}-\mathrm{NMR}$ spectrum, of 5, shows that only remains the double bond adjacent to the sulfonyl group, signals corresponding to $\mathrm{H}-1^{\prime}(6.90 \mathrm{ppm}, \mathrm{dd}, J=15.1$ and $7.6 \mathrm{~Hz})$ and $\mathrm{H}-2$ ' $(6.31 \mathrm{ppm}, \mathrm{d}, J=15.1 \mathrm{~Hz})$. The constant $15.1 \mathrm{~Hz}$ indicates that the double bond between $\mathrm{C}-1$ ' and C-2' keeps the Egeometry from the double bond of the starting material, see figure 4.

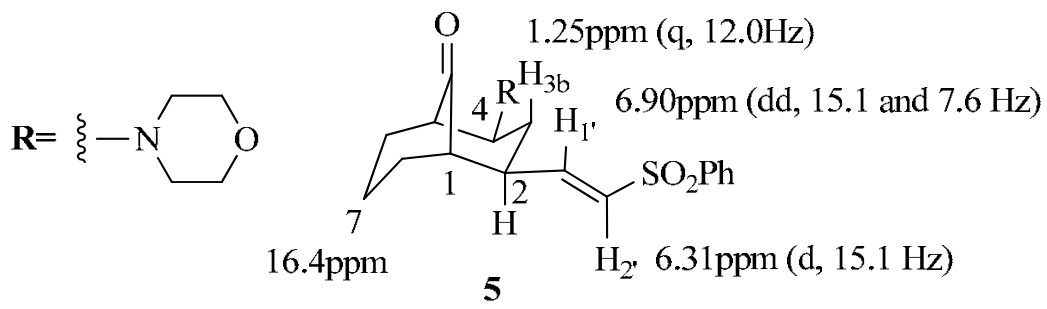

Figure 4. Compound 5. 
The axial hydrogen of $\mathrm{C}-3$ in 5 resonates as a quartet at $1.25 \mathrm{ppm}(J=12.0 \mathrm{~Hz})$ similarly to 4a. Its shielding indicates the chair-boat situation of the bicycle, which is corroborated by the C7 shifting (16.5 ppm) in its ${ }^{13} \mathrm{C}-\mathrm{NMR}$ spectrum, under $20 \mathrm{ppm}$.

\section{Reactivity with 4-(1-cyclopentenyl)morpholine}

Once observed the reactivity of our compound with 4-(1-cyclohexenyl)morpholine, originating bicyclo[3.3.1]non-9-ones, it was reasonable to think that the same cyclization type would happen with 4-(1-cyclopentenyl)morpholine, resulting bicyclo[3.2.1]octen-9-nonanes.

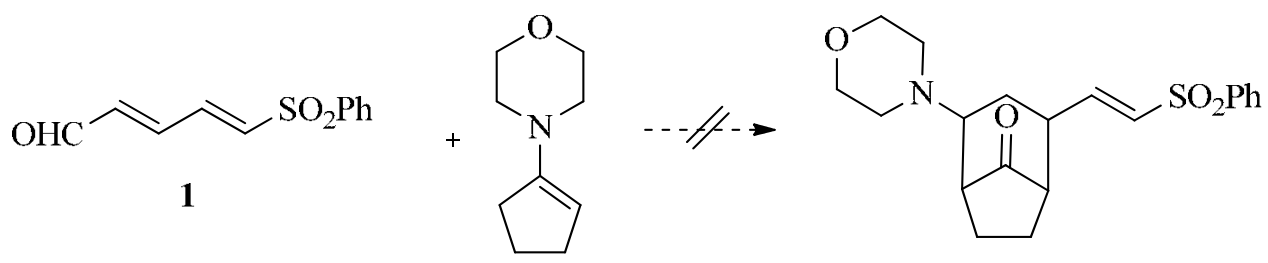

Figure 5. Reaction of 1 with 4-(1-cyclopentenyl)morpholine.

When 1 is treated with 4-(1-cyclopentenyl)morpholine at $0^{\circ} \mathrm{C}$ in dry 1,4-Dioxane, leaving the mixture to warm up to room temperature, no cyclization product is observed. However, the decomposition of the starting material occurs, figure 5 . These results agree with studies found in literature, in which the reaction of acrolein with 4-(1-cyclohexenyl)morpholine leads bicyclo[3.3.1]nonan-9 one with a yield of at least $60 \%$. Whereas when the enamine 4-(1cyclopentenyl)morpholine is used, in the same former conditions, only bicyclo[3.2.1] octan-9-one is obtained with a yield of $5 \% .^{11}$

\section{Reactivity with 1-cyclohexen-1-enyl-pyrrolidine}

The next enamine studied for the reaction with 1 was 1-cyclohexen-1-enyl-pyrrolidine, Table 2.

Table 2. Reaction of 1 with 1-cyclohexen-1-enyl-pyrrolidine:

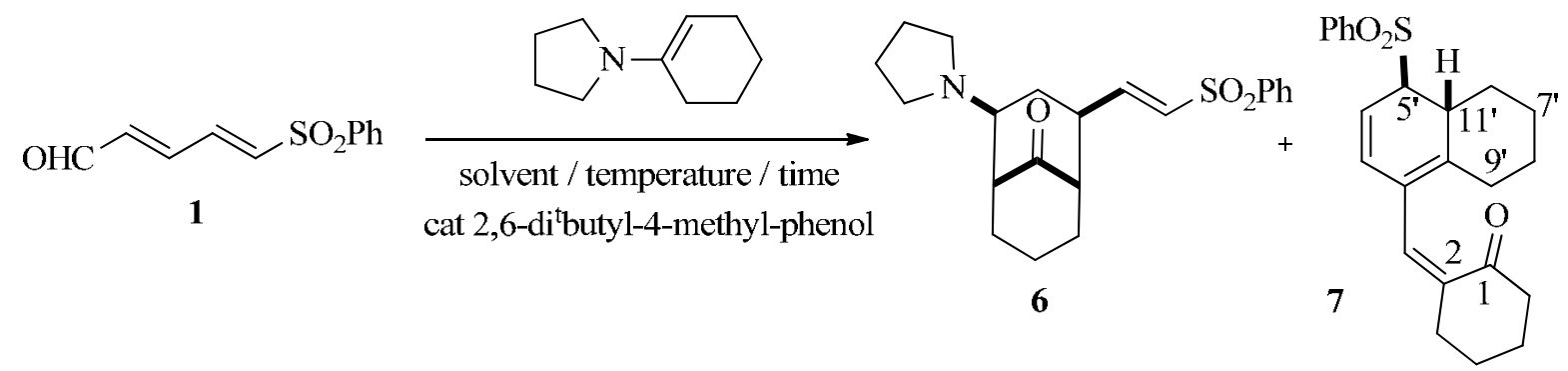




\begin{tabular}{ccccccc}
\hline \multirow{2}{*}{ Entry } & \multirow{2}{*}{$1 / \mathrm{mmol}^{\mathrm{a}}$} & \multirow{2}{*}{ Solvent } & \multirow{2}{*}{$\mathrm{T} /{ }^{\circ} \mathrm{C}$} & $\mathrm{t}$ & $\mathbf{6 ( \% )}$ & $\mathbf{7 ( \% )}$ \\
\hline 1 & 0.30 & $\mathrm{DCM}$ & 20 & 3 days & 0 & 11 \\
2 & 1.12 & $\mathrm{Et}{ }_{2} \mathrm{O}$ & 20 & 3 days & 0 & 0 \\
3 & 0.42 & $\mathrm{THF}$ & 20 & $12 \mathrm{~h}$ & 64 & 12 \\
\hline
\end{tabular}

${ }^{\mathrm{a}}$ All experiments were carried out using 5 equivalents of enamine per each equivalent of $\mathbf{1}$.

After chromatography of the mixture obtained in entry 1, compound 7 was isolated as a pure compound although in low yield. The structure of 7 was established unequivocally by mono and bidimensional NMR studies. In its ${ }^{1} \mathrm{H}-\mathrm{NMR}$ spectrum, the olefinic hydrogens corresponding to H-4' and H-3' appear at 5.65 ppm (H-4', dd, $J=11.4$ and $5.7 \mathrm{~Hz})$ and $5.90 \mathrm{ppm}(\mathrm{H}-3$ ', d, J= 11.4 $\mathrm{Hz}$ ) respectively, see Figure 6.
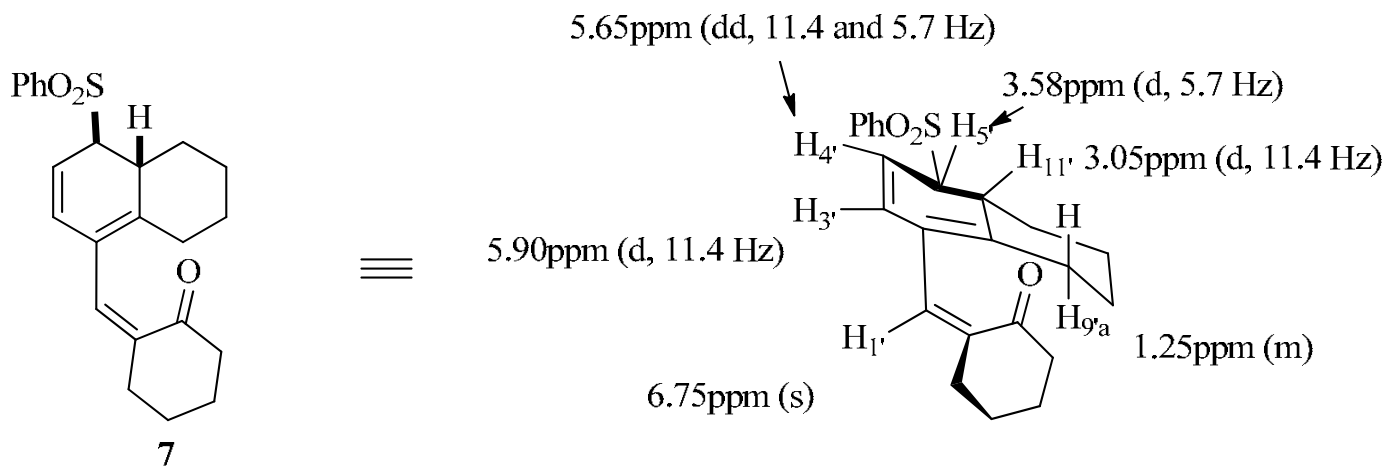

Figure 6. Spectroscopic data for 7.

The hydrogen $\mathrm{H}-5^{\prime}$, appears at $3.58 \mathrm{ppm}$ as a doublet of constant $J=5.7 \mathrm{~Hz}$, showing that it forms an angle of $90^{\circ}$ with $\mathrm{H}-11^{\prime}$. These facts clearly demonstrate the trans stereochemistry between both hydrogens. The geometry of the double bond between positions 1' and 2 is cis, since the hydrogen H-9' $\alpha$, appears very shielded at $1.25 \mathrm{ppm}$ in its ${ }^{1} \mathrm{H}-\mathrm{NMR}$ spectrum, due to the carbonyl of cyclohexanone. If the double bond were trans, the carbonyl anisotropy cone would not affect to any hydrogen of the bicycle. Likewise, the hydrogen at 1' appears as a singlet at $6.75 \mathrm{ppm}$, which means that it is not affected by the carbonyl of the cyclohexanone. In case it was affected, it should appear over $7.00 \mathrm{ppm}$. In ether the reaction did not work at all, entry 2 . In entry 3 , we were able to see compound $\mathbf{6}$ as major compound in the mixture. The fractions of the chromatography enriched with compound 6 (bicyclo[3.3.1]nonan-9-one) were analyzed by ${ }^{1} \mathrm{H}-\mathrm{NMR}$. The more characteristic signals of 6 are: $7.00 \mathrm{ppm}(1 \mathrm{H}, \mathrm{dd}, J=16.0$ and $8.0 \mathrm{~Hz}, \mathrm{H}-1$ '), $6.30 \mathrm{ppm}\left(1 \mathrm{H}, \mathrm{d}, J=16.0 \mathrm{~Hz}, \mathrm{H}-2^{\prime}\right), 2.90 \mathrm{ppm}(1 \mathrm{H}, \mathrm{m}, \mathrm{H}-4)$. The structure and stereochemistry are determined subsequently.

In order to establish the stereochemistry of $\mathbf{6}$, the mixture enriched in $\mathbf{6}$, was submitted to treatment with phenylchloroformate to obtain compound $\mathbf{8}$. Scheme 2. 


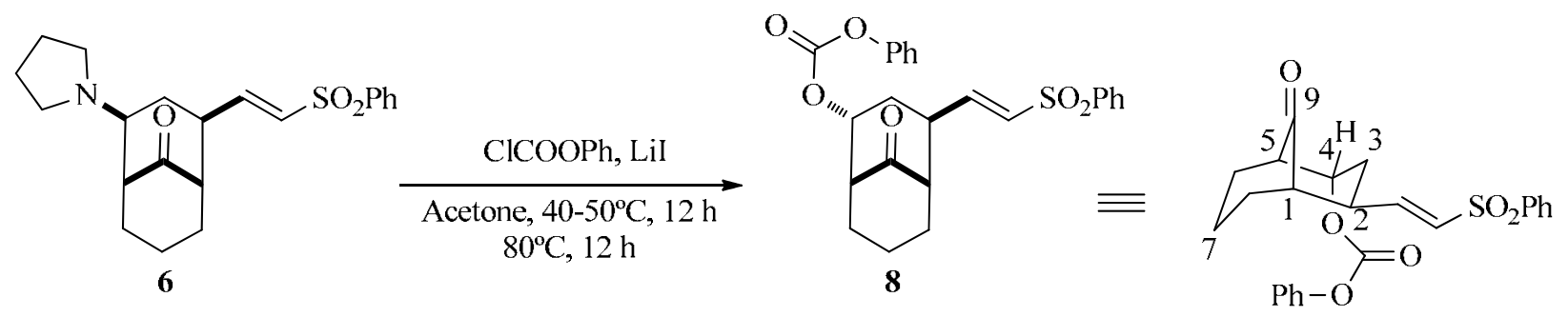

Scheme 2. Reaction of 6 with phenylchloroformate.

The structure of 8 was established unequivocally by NMR. The chair-boat conformation, with the C-4 axial substituent is confirmed by signal corresponding to H-5 as a doublet at 2.25 ppm of coupling constant $J=9.1 \mathrm{~Hz}$, the same constant as $\mathrm{H}-4$, hence the chair-boat conformation with the C-4 axial substituent. The hydrogen at C-2, being in the same plane than the phenylcarbonate substituent is shielded to $3.40 \mathrm{ppm}$. The formation of $\mathbf{8}$ involves two molecules of phenylchloroformate as it is shown in figure $7 .{ }^{12}$

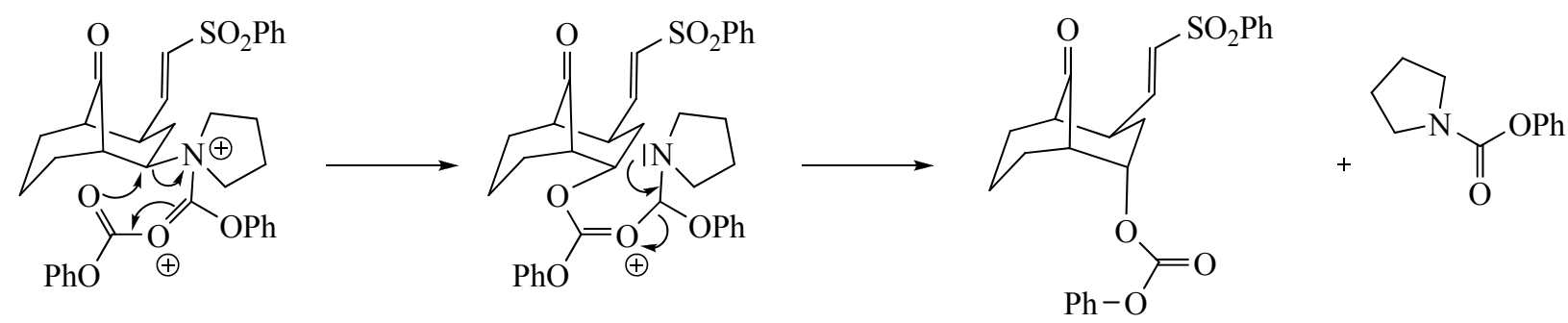

Figure 7. Mechanism for the reaction of 6 to 8 .

It is important to note the inversion of the configuration at C-4, which confirms the former structure proposed for 6 .

\section{Ginsenol analogues}

Once obtained our desired compounds $\mathbf{5}$ and $\mathbf{8}$ we decided to do the cyclization in order to obtain Ginsenol analogues.

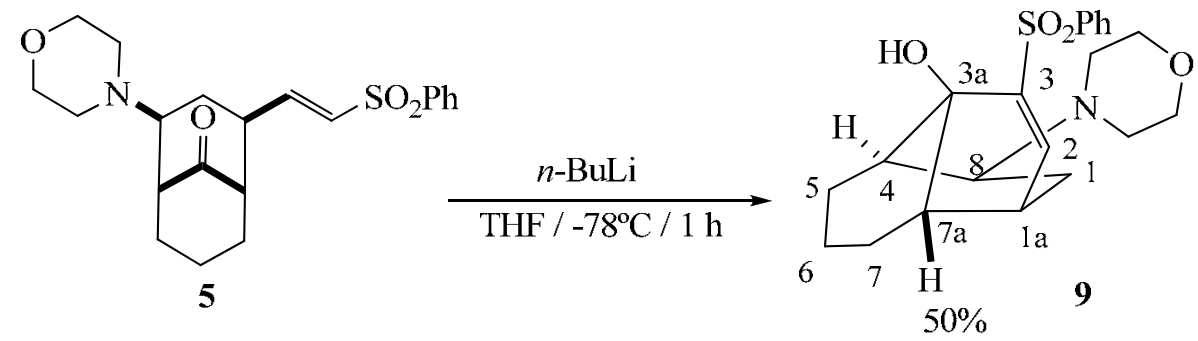


Scheme 3. Cyclization reaction of 5 for Ginsenol analogues.

The basic Ginsenol framework is easily accessible from the bicyclic compound 5, as there is a vinyl sulfone and a carbonyl group. The existing chair-boat conformation and the equatorial position of the substituent containing the sulfonyl group approach these two groups in space, which facilitate the reaction between them. Treating 5 with $n$-butyl lithium gives the tricyclic compound 9, scheme 3, which structure is unequivocally determined by ${ }^{13} \mathrm{C}-\mathrm{NMR}$. It was observed the signal of a tetrasubstituted oxygenated carbon at $79.1 \mathrm{ppm}$, and the disappearance of the conjugated olefinic system of the sulfonyl group, appearing only a signal corresponding to the olefinic methyl at $150.3 \mathrm{ppm}$.

Compound 9 shows a chair-boat conformation confirmed by the chemical shifting of its C-6 carbon (18.7 ppm) below $20 \mathrm{ppm}$, in its ${ }^{13} \mathrm{C}-\mathrm{NMR}$ spectrum ${ }^{7}$. Compound 8 was chosen as starting material with the purpose of synthesizing analogues without nitrogen substituents. It has an axial carbonate at C-4. When $\mathbf{8}$ is treated with $n$-butyl lithium in the same former conditions, $\mathbf{1 0}$ is obtained, see Scheme 4.
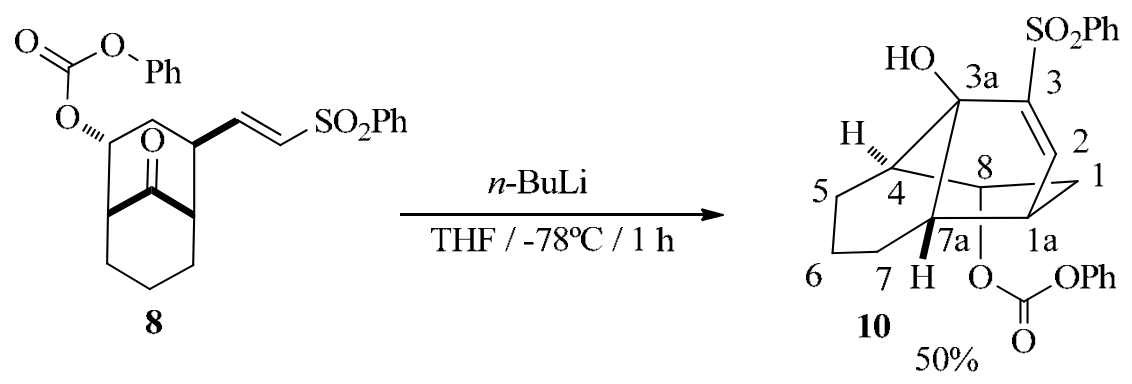

Scheme 4. Cyclization reaction of 9 for Ginsenol analogues.

The structure of $\mathbf{1 0}$ is established by NMR. Its conformation is the same as 9, since its C-6 carbon appears at $18.2 \mathrm{ppm}$ in its ${ }^{13} \mathrm{C}$-NMR spectrum. ${ }^{7}$

\section{Conclusions}

In this communication, we have described that sulfonylbutadienes are good starting materials for the synthesis of bicyclo[3.3.1] systems. These compounds have been used for the synthesis of Ginsenol analogues.

\section{Experimental Section}


General. Unless otherwise stated, all chemicals were purchased as the highest purity commercially available and were used without further purification. IR spectra were recorded on a BOMEM 100 FT-IR or an AVATAR 370 FT-IR Thermo Nicolet spectrophotometers. ${ }^{1} \mathrm{H}$ and ${ }^{13} \mathrm{C}$-NMR spectra were performed in $\mathrm{CDCl}_{3}$ and referenced to the residual peak of $\mathrm{CHCl}_{3}$ at $\delta$ $7.26 \mathrm{ppm}$ and $\delta 77.0 \mathrm{ppm}$, for ${ }^{1} \mathrm{H}$ and ${ }^{13} \mathrm{C}$, respectively, using Varian $200 \mathrm{VX}$ and Bruker DRX 400 instruments. Chemical shifts are reported in $\delta$ ppm and coupling constants $(J)$ are given in hertz. MS were performed at a VG-TS 250 spectrometer at $70 \mathrm{eV}$ ionizing voltage. Mass spectra are presented as $m / z$ (\% rel int.). HRMS were recorded on a VG Platform (Fisons) spectrometer using chemical ionization (ammonia as gas) or Fast Atom Bombardment (FAB) technique. For some of the samples, QSTAR XL spectrometer was employed for electrospray ionization (ESI). Optical rotations were determined on a Perkin-Elmer 241 polarimeter in $1 \mathrm{dm}$ cells. Diethyl ether and THF were distilled from sodium, and dichloromethane was distilled from calcium hydride under argon atmosphere.

\section{Reactivity of aldehydes $2 E / 3 Z$ with enamines}

Reactivity with 4-(1-cyclohexenyl)morpholine: $\left(2 S^{*}, 4 R^{*}\right)-2-(2-p h e n y l s u l f o n y l-1 '-m e t h y l-$ E/Z-vinyl)-4-morpholinylbicyclo[3.3.1]nonan-9-one, (4a/4b)

To a solution of aldehydes $\mathbf{2 E} / 3 \mathbf{Z}$ mixture (85:15 ratio) $(166 \mathrm{mg}, 0.70 \mathrm{mmol})$ in DCM (1 mL), a catalytic amount of 2,6-di-tert-butyl-4- methylphenol is added as radical activator followed by 4(1-cyclohexenyl)morpholine $(1.5 \mathrm{~mL}, 8.9 \mathrm{mmol})$. The mixture is stirred under Argon and left at room temperature for 6 days. After removing the solvent, the product is purified by flash chromatography (silica gel, eluting with $\left.\mathrm{CHCl}_{3}\right)$ to yield $4 \mathbf{a}(79.7 \mathrm{mg}, 28 \%), \mathbf{4 a} / \mathbf{4 b} \mathrm{mix}(22.4$ $\mathrm{mg}, 3: 1$ ratio, $8 \%$ ), and the excess of starting enamine. The mixture $\mathbf{4 a} / \mathbf{4 b}$ is purified again, being impossible to separate $\mathbf{4 b}$ completely. Spectroscopic properties of $\mathbf{4 b}$ are deduced from the spectroscopy of a mixture $\mathbf{4 a} \mathbf{a} \mathbf{4 b}$, very enriched in $\mathbf{4 b}$.

4a. IR (film) v ( $\left.\mathrm{cm}^{-1}\right): 2942,2857,1713,1447,1377,1302,1250,1146,1117,1086,1001,754$, 691; ${ }^{1} \mathrm{H}-\mathrm{NMR} \delta(\mathrm{ppm})\left(400 \mathrm{MHz}, \mathrm{CDCl}_{3}\right): 7.90(2 \mathrm{H}, \mathrm{m}, \mathrm{Ar}), 7.62(1 \mathrm{H}, \mathrm{m}, \mathrm{Ar}), 7.54$ (2H, m, Ar), 6.24 (1H, s, H-2'), 3.66 (4H, t, J=4.5 Hz, H-3', , H-5' '), 2.95 (1H, dt, J= 12.6 and $2.0 \mathrm{~Hz}, \mathrm{H}-4$ ), 2.59 (1H, m, H-2), 2.55 (1H, m, H-5), 2.48 (4H, t, J=4.5 Hz, H-2' ', H-6' '), 2.25 (1H, br s, H-1), 2.08 (3H, s, Me-C-1'), 2.00-1.80 (6H, m, H-6, H-7, H-8), 1.70 (1H, dt, J= 12.6 and $2.0 \mathrm{~Hz}, \mathrm{H \alpha}-$

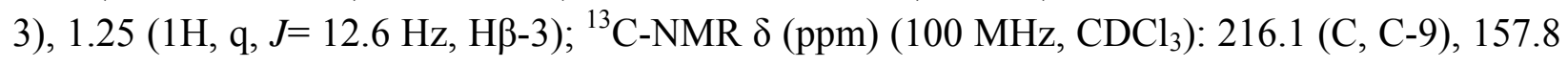
(C, C-1'), 141.8 (C, C-ipso Ar), 133.3 (CH para Ar), 129.2 (2CH meta Ar), 127.1 (2CH ortho

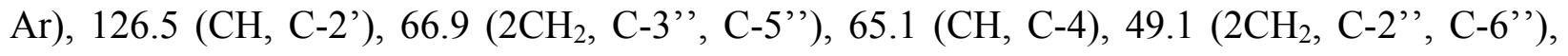
49.1 (CH, C-5), 48.6 (CH, C-1), 46.9 (CH, C-2), $34.5\left(\mathrm{CH}_{2}, \mathrm{C}-6\right), 34.2\left(\mathrm{CH}_{2}, \mathrm{C}-8\right), 27.7\left(\mathrm{CH}_{2}, \mathrm{C}-\right.$ 3), $16.3\left(\mathrm{CH}_{2}, \mathrm{C}-7\right), 15.1\left(\mathrm{CH}_{3}, \mathrm{Me}-\mathrm{C}-1^{\prime}\right)$. HRMS calcd for $\mathrm{C}_{22} \mathrm{H}_{29} \mathrm{NNaO}_{4} \mathrm{~S} 426.1715\left(\mathrm{M}+\mathrm{Na}^{+}\right)$, found 426.1718. The structure is checked by X-Ray experiments, HMQC, HMBC and irradiation experiments.

Crystal data for (4a). $\mathrm{C}_{22} \mathrm{H}_{29} \mathrm{NO}_{4} \mathrm{~S}, M=403.52$, monoclinic, $C c$ (no. 9), $a=10.5816(13), b=$ 78.857(6), $c=8.1756(9) \AA, \beta=114.035(7)^{\circ}, V=6230.5(12) \AA^{3}, Z=12$ (three independent molecules $), D_{\mathrm{c}}=1.291 \mathrm{~g} \mathrm{~cm}^{-3}, \mu(\mathrm{Cu}-\mathrm{K} \alpha)=1.609 \mathrm{~mm}^{-1}, T=293 \mathrm{~K}$, yellow blocks, Siemens P4 
diffractometer; 5315 independent measured reflections $\left(R_{\mathrm{int}}=0.0333\right), F^{2}$ refinement, $R_{1}(\mathrm{obs})=$ $0.0573, w R_{2}($ all $)=0.1498,4265$ independent observed absorption-corrected reflections $\left[\left|F_{0}\right|>\right.$ $\left.4 \sigma\left(\left|F_{\mathrm{o}}\right|\right), 2 \theta_{\max }=127^{\circ}\right], 782$ parameters. The absolute structure of $4 \mathbf{a}$ was determined by a combination of $R$-factor tests $\left[R_{1}{ }^{+}=0.0573, R_{1}^{-}=0.0611\right]$ and by use of the Flack parameter $\left[x^{+}\right.$ $\left.=+0.09(4), x^{-}=+0.91(4)\right]$. CCDC 766005. For additional data see supporting information.

4b. ${ }^{1} \mathrm{H}-\mathrm{NMR} \delta(\mathrm{ppm})\left(200 \mathrm{MHz}, \mathrm{CDCl}_{3}\right):$ 7.90-7.80 (2H, m, Ar), 7.60-7.50 (3H, m, Ar), 6.20 (1H, s, H-2'), 4.15 (1H, dt, J= 12.6 and 2.0 Hz, H-2), 3.65 (4H, t, J=4.5 Hz, H-3', H-5' '), 2.95 $(1 \mathrm{H}, \mathrm{dt}, J=12.6$ and $2.0 \mathrm{~Hz}, \mathrm{H}-4), 2.50(1 \mathrm{H}, \mathrm{m}, \mathrm{H}-5), 2.45$ (4H, m, H-2', $\mathrm{H}-6$ ') $) 2.20(1 \mathrm{H}, b r$ s, H-1), 2.00-1.60 (6H, m, H-6, H-7, H-8), 1.79 (3H, s, Me-C-1'), $1.50(1 \mathrm{H}, \mathrm{dt}, J=12.6$ and $2 \mathrm{~Hz}$, $\mathrm{H \alpha}-3), 1.25(1 \mathrm{H}, \mathrm{q}, J=12.6 \mathrm{~Hz}, \mathrm{H} \beta-3) ;{ }^{13} \mathrm{C}-\mathrm{NMR} \delta(\mathrm{ppm})\left(50 \mathrm{MHz}, \mathrm{CDCl}_{3}\right): 217.0(\mathrm{C}, \mathrm{C}-9)$, 157.4 (C, C-1'), 143.0 (C, C-ipso Ar), 133.2 (CH para Ar), 129.2 (2CH meta Ar), 127.7 (CH, C2'), 127.1 (2CH ortho Ar), 67.0 (2CH 2 , C-3', C-5'), 65.7 (CH, C-4), $49.3\left(2 \mathrm{CH}_{2}, \mathrm{C}-2\right.$ ', C-6'), $49.3(\mathrm{CH}, \mathrm{C}-5), 48.7(\mathrm{CH}, \mathrm{C}-1), 37.0(\mathrm{CH}, \mathrm{C}-2), 34.7\left(\mathrm{CH}_{2}, \mathrm{C}-6\right), 33.3\left(\mathrm{CH}_{2}, \mathrm{C}-8\right), 27.1\left(\mathrm{CH}_{2}, \mathrm{C}-\right.$ 3), $19.6\left(\mathrm{CH}_{3}, \mathrm{Me}-\mathrm{C}-1^{\prime}\right), 16.8\left(\mathrm{CH}_{2}, \mathrm{C}-7\right)$.

\section{Reactivity of 1 with different enamines}

Reactivity with 4-(1-cyclohexenyl)morpholine: $\left(2 R^{*}, 4 S^{*}\right)-2-(2$ '-phenylsulfonyl- $E$-vinyl)-4morpholinylbicyclo[3.3.1]nonan-9-one (5). General procedure

To a solution of the aldehyde $\mathbf{1}$ in the proper solvent, a catalytic amount of 2,6-di-tert-butyl-4methylphenol is added. The temperature of the mixture is then lowered to $0^{\circ} \mathrm{C}$ and 4 (cyclohexenyl)morpholine (5 equivalents) is added. The mixture is stirred at room temperature under Argon during the specified time. Next, the solvent is removed under vacuum, and the product is extracted with ethyl acetate. The combined organic layers are washed with brine, dried over $\mathrm{Na}_{2} \mathrm{SO}_{4}$, filtered, and concentrated. The resulting crude is purified by flash chromatography (silica gel, $\mathrm{CHCl}_{3} / \mathrm{MeOH}$ mixtures).

Depending on the solvent used, entries table 1:

1. Dry 1,4-Dioxane: Reaction time: 5 days. $1(136 \mathrm{mg}, 0.61 \mathrm{mmol})$ in dry 1,4-Dioxane (2 $\mathrm{mL})$ and 4-(1-cyclohexenyl)morpholine $(0.5 \mathrm{~mL}, 3.05 \mathrm{mmol})$. Obtained $5(90 \mathrm{mg}, 38 \%)$

2. Dry DCM: Reaction time: 12 hours. $1(15 \mathrm{mg}, 0.07 \mathrm{mmol})$ in dry DCM $(0.5 \mathrm{~mL})$ and $4-$ (1-cyclohexenyl)morpholine ( $0.06 \mathrm{~mL}, 0.35 \mathrm{mmol})$. Obtained $5(13.5 \mathrm{mg}, 50 \%)$.

3. Dry DCM: Reaction time: 5 days. $1(45 \mathrm{mg}, 0.20 \mathrm{mmol})$ in dry DCM $(1 \mathrm{~mL})$ and 4-(1cyclohexenyl)morpholine (0.2 mL, $1.0 \mathrm{mmol})$. Obtained 5 (47 mg, 60\%).

4. Dry DCM: Reaction time: 12 hours. $1(363 \mathrm{mg}, 1.63 \mathrm{mmol})$ in dry DCM $(10 \mathrm{~mL})$ and 4(1-cyclohexenyl)morpholine (1.3 mL, $8.14 \mathrm{mmol})$. Obtained 1 (109 mg), b) 5 (286 mg, 45\%).

5. IR (film) v ( $\left.\mathrm{cm}^{-1}\right): .2940,2857,1713,1630,1447,1306,1148,1117,1088,1015,918,729$, 689; ${ }^{1} \mathrm{H}-\mathrm{NMR} \delta(\mathrm{ppm})\left(400 \mathrm{MHz}, \mathrm{CDCl}_{3}\right): 7.90(2 \mathrm{H}, \mathrm{m}, \mathrm{Ar}), 7.61(1 \mathrm{H}, \mathrm{m}, \mathrm{Ar}), 7.55(2 \mathrm{H}, \mathrm{m}, \mathrm{Ar})$, $6.90\left(1 \mathrm{H}, \mathrm{dd}, J=15.1\right.$ and $\left.7.6 \mathrm{~Hz}, \mathrm{H}-1^{\prime}\right), 6.31\left(1 \mathrm{H}, \mathrm{brd}, J=15.1 \mathrm{~Hz}, \mathrm{H}-2^{\prime}\right), 3.67(4 \mathrm{H}, \mathrm{t}, J=4.2 \mathrm{~Hz}$, H-3", H-5'), 3.00 (1H, dt, J= 12.0 and $4.2 \mathrm{~Hz}, \mathrm{H}-4), 2.75(1 \mathrm{H}, \mathrm{m}, \mathrm{H}-2), 2.55$ (1H, br s, H-5),

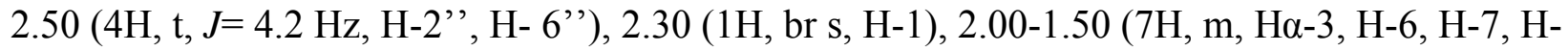
8), $1.25(1 \mathrm{H}, \mathrm{q}, J=12.0 \mathrm{~Hz}, \mathrm{H} \beta-3) ;{ }^{13} \mathrm{C}-\mathrm{NMR} \delta(\mathrm{ppm})\left(100 \mathrm{MHz}, \mathrm{CDCl}_{3}\right): 215.8$ (C, C-9), 147.8 (CH, C-1'), 140.1 (C, C-ipso Ar), 133.5 (CH para Ar), 129.7 (CH, C-2'), 129.4 (2CH meta Ar), 
127.6 (2CH ortho Ar), $66.8\left(2 \mathrm{CH}_{2}, \mathrm{C}-3\right.$ ',, $\mathrm{C}-5$ ' '), $65.6(\mathrm{CH}, \mathrm{C}-4), 49.6(\mathrm{CH}, \mathrm{C}-5), 49.1\left(2 \mathrm{CH}_{2}\right.$, C-2', C-6' '), 48.5 (CH, C-1), 39.3 (CH, C-2), $34.5\left(\mathrm{CH}_{2}, \mathrm{C}-6\right), 33.9\left(\mathrm{CH}_{2}, \mathrm{C}-8\right), 28.3\left(\mathrm{CH}_{2}, \mathrm{C}-\right.$ 3), $16.5\left(\mathrm{CH}_{2}, \mathrm{C}-7\right)$. HRMS calcd for $\mathrm{C}_{21} \mathrm{H}_{27} \mathrm{NNaO}_{4} \mathrm{~S} 412.1558\left(\mathrm{M}+\mathrm{Na}^{+}\right)$, found 412.1551 .

\section{Reactivity with 4-(1-cyclopentenyl)morpholine}

To a solution of aldehyde $1(24.2 \mathrm{mg}, 0.11 \mathrm{mmol})$ in dry 1,4-Dioxane $(1.5 \mathrm{~mL})$, a catalytic amount of 2,6-di-tert-butyl-4-methylphenol is added. The temperature is then lowered to $0^{\circ} \mathrm{C}$ and 4 -(1-cyclopentenyl)morpholine $(0.1 \mathrm{~mL}, 0.54 \mathrm{mmol})$ is added. The mixture is stirred at room temperature under Argon for 3 days. Then, the solvent is removed under vacuum and the product is extracted with ethyl acetate. The combined organic layers are washed with brine, dried over $\mathrm{Na}_{2} \mathrm{SO}_{4}$, filtered, and concentrated. The resulting crude is purified by flash chromatography (silica gel, $\mathrm{CHCl}_{3} / \mathrm{MeOH}$ ).

Reactivity with 1-cyclohexen-1-enyl-pyrrolidine: $\left(2 R^{*}, 4 S^{*}\right)-2-\left(2^{\prime}-\right.$ phenylsulfonyl-E-vinyl)-4pyrrolidinylbicyclo[3.3.1]nonan-9-one (6), (5'S*,11' $\left.S^{*}\right)-2-\left(5^{\prime}\right.$-phenylsulfonyl-5',11',6',7',8', 9'-hexahydronaphtalen-1'-methylen)cyclohexanone (7). General procedure

To a solution of the aldehyde $\mathbf{1}$ in the proper solvent, a catalytic amount of 2,6-di-tert-butyl-4methylphenol is added. The temperature is then lowered to $0^{\circ} \mathrm{C}$ and 1 - cyclohexenylpyrrolidine is added. The mixture is stirred at room temperature under Argon during the specified time. Then, the solvent is removed under vacuum and the product is extracted with ethyl acetate. The combined organic layers are washed with brine, dried over $\mathrm{Na}_{2} \mathrm{SO}_{4}$, filtered, and concentrated. The resulting crude is purified by flash chromatography (silica gel, $n$-Hexane/ EtOAc mixtures).

Detailed experiments, entries table 2:

1. Reaction time: 3 days. Used amounts: 1 (66 mg, $0.30 \mathrm{mmol})$ in dry DCM (2 mL) and 1cyclohexen-1-enyl-pyrrolidine (0.24 mL, $1.50 \mathrm{mmol})$. Obtained 7 (13 mg, 11\%).

2. Reaction time: 3 days. Used amounts: 1 (250 mg, $1.12 \mathrm{mmol})$ in $\operatorname{dry}_{\mathrm{Et}_{2}} \mathrm{O}(6 \mathrm{~mL})$ and 1cyclohexen-1-enyl-pyrrolidine $(0.90 \mathrm{~mL}, 5.6 \mathrm{mmol})$. Decomposition.

3. Reaction time: 12 hours under Argon. 1 (94 mg, $0.42 \mathrm{mmol})$ in dry THF (1 mL) and 1cyclohexen-1-enyl-pyrrolidine $(0.07 \mathrm{~mL}, 0.42 \mathrm{mmol})$. Obtained $7(20 \mathrm{mg}, 12 \%)$, and a mixture that after chromatography with $n$-hexane/EtAcO 1/1, were $100 \mathrm{mg}(64 \%)$ of a mixture where bicycle $\mathbf{6}$ is the main compound.

6. IR (film) v (cm-1): 3059, 2940, 2857, 1713, 1630, 1603, 1447, 1306, 1148, 1117, 1088, 1015, 918, 729, 689; ${ }^{1} \mathrm{H}-\mathrm{NMR} \delta(\mathrm{ppm})\left(200 \mathrm{MHz}, \mathrm{CDCl}_{3}\right): 7.85-7.81(2 \mathrm{H}, \mathrm{m}, \mathrm{Ar}), 7.60-7.50(3 \mathrm{H}, \mathrm{m}$, Ar), 7.00 (1H, dd, $J=16.0$ and $\left.8.0 \mathrm{~Hz}, \mathrm{H}-1^{\prime}\right), 6.30$ (1H, d, $J=16.0 \mathrm{~Hz}, \mathrm{H}-2$ '), 2.90 (1H, m, H-4).

7. IR (film) v ( $\left.\mathrm{cm}^{-1}\right): 2934,2857,1705,1684,1603,1447,1304,1136,1082,725,691 ;{ }^{1} \mathrm{H}-\mathrm{NMR}$ $\delta(\mathrm{ppm})\left(400 \mathrm{MHz}, \mathrm{CDCl}_{3}\right): 7.83-7.80(2 \mathrm{H}, \mathrm{m}, \mathrm{Ar}), 7.60(1 \mathrm{H}, \mathrm{m}, \mathrm{Ar}), 7.45(2 \mathrm{H}, \mathrm{m}, \mathrm{Ar}), 6.75(1 \mathrm{H}$, s, H-1'), 5.90 (1H, d, $J=11.4 \mathrm{~Hz}, \mathrm{H}-3$ '), 5.65 (1H, dd, $J=11.4$ and $5.7 \mathrm{~Hz}, \mathrm{H}-4$ '), 3.58 (1H, d, $J=$ 5.7 Hz, H-5'), 3.05 (1H, d, J=11.4 Hz, H-11'), 2.40 (2H, t, J=6.8 Hz, H-6), 2.30 (1H, d, J= 12.6

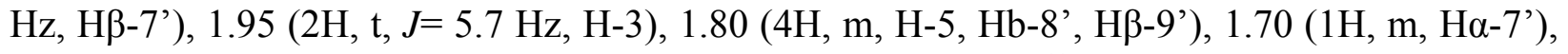
1.65-1.50 (5H, m, Ha-8', H-6', H-4), 1.25 (1H, m, H $\alpha-9$ '); ${ }^{13} \mathrm{C}-\mathrm{NMR} \delta(\mathrm{ppm})(100 \mathrm{MHz}$, 
$\mathrm{CDCl}_{3}$ ): 201.4 (C, C-1), 145.0 (C, C-10'), 137.4(C, C-2), 136.8 (C, C-ipso Ar), 133.6 (CH para $\mathrm{Ar}), 132.6\left(\mathrm{CH}, \mathrm{C}-1^{\prime}\right), 131.0\left(\mathrm{CH}, \mathrm{C}-3^{\prime}\right), 129.6$ (2CH meta $\left.\mathrm{Ar}\right), 128.4$ (2CH ortho Ar), 120.5 (C, C-2'), 112.9 (CH, C-4'), 67.7 (CH, C-5'), $40.3\left(\mathrm{CH}_{2}, \mathrm{C}-6\right), 39.9$ (CH, C-11'), 37.9 (CH, C-6'), $32.4\left(\mathrm{CH}_{2}, \mathrm{C}-7^{\prime}\right), 30.3\left(\mathrm{CH}_{2}, \mathrm{C}-9\right.$ ') $28.6\left(\mathrm{CH}_{2}, \mathrm{C}-3\right), 26.9\left(\mathrm{CH}_{2}, \mathrm{C}-8\right.$ ') $, 23.9\left(\mathrm{CH}_{2}, \mathrm{C}-4\right), 23.5$ $\left(\mathrm{CH}_{2}, \mathrm{C}-5\right)$. MS, EI, m/z (relative intensity, \%): 240 (100) [M+-142 $\left.\left(\mathrm{SO}_{2} \mathrm{Ph}\right)\right], 223$ (30) [240-17 (OH lost)], 197 (76), 141 (73), 128 (55), 115 (53).

\section{Synthesis of $\left(2 R^{*}, 4 S^{*}\right)-(2$ 'phenylsulfonyl- $E$-vinyl)-4-phenylcarbonate-bicyclo[3.3.1]nonan- 9-one, (8)}

To a solution of $6(100 \mathrm{mg}, 0.27 \mathrm{mmol})$ in dry acetone $(4 \mathrm{~mL})$, lithium iodide $(253 \mathrm{mg}, 1.89$ $\mathrm{mmol}$ ) is added followed by phenyl chloroformate $80.05 \mathrm{~mL}, 0.4 \mathrm{mmol}$ ) at room temperature under Argon. The mixture is heated to $40^{\circ} \mathrm{C}-50^{\circ} \mathrm{C}$ for 12 hours. Next, the temperature is raised up to $80^{\circ} \mathrm{C}$ and the mixture is stirred under these conditions during 12 hours more. The reaction is quenched with water. The product is extracted with ethyl acetate, and the organic layers are washed with water and brine, dried over $\mathrm{Na}_{2} \mathrm{SO}_{4}$, filtered and concentrated. The crude is purified by flash chromatography (silica gel, $n$-Hexane/AcOEt 1/1). The next fractions are collected: a) 8 (37 mg).

8. IR (film) v ( $\left.\mathrm{cm}^{-1}\right): 3065,2934,2859,1717,1456,1420,1373,1317,1204,1148,1089,754$; ${ }^{1} \mathrm{H}-\mathrm{NMR} \delta(\mathrm{ppm}):\left(400 \mathrm{M} \mathrm{Hz}, \mathrm{CDCl}_{3}\right): 7.87$ (2H, m, Ar1), $7.64(1 \mathrm{H}, \mathrm{m}, \mathrm{Ar} 1), 7.55$ (2H, m, Ar2), $7.36(2 \mathrm{H}, \mathrm{m}, \mathrm{Ar} 1), 7.20(1 \mathrm{H}, \mathrm{m}, \mathrm{Ar} 2), 7.09(2 \mathrm{H}, \mathrm{m}, \mathrm{Ar} 2), 6.90(1 \mathrm{H}, \mathrm{dd}, J=15.5$ and $6.6 \mathrm{~Hz}, \mathrm{H}-$

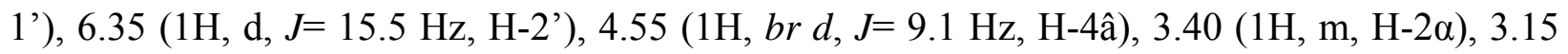

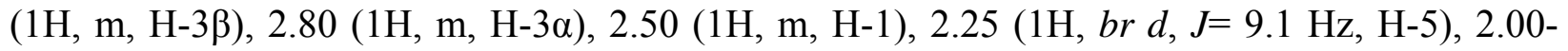
$1.50(6 \mathrm{H}, \mathrm{m}, \mathrm{H}-6, \mathrm{H}-7, \mathrm{H}-8) ;{ }^{13} \mathrm{C}-\mathrm{NMR} \delta(\mathrm{ppm})\left(100 \mathrm{M} \mathrm{Hz}, \mathrm{CDCl}_{3}\right): 214.6(\mathrm{C}, \mathrm{C}-9), 154.0(\mathrm{C}$, C-2'”), 150.9 (C-ipso Ar2), 147.0 (CH, C-1'), 139.9 (C-ipso Ar1), 133.6 (CH para Ar1), 130.1 (CH, C-2'), 129.4 (2CH meta Ar1), 129.3 (2CH meta Ar2), 127.7 (2CH ortho Ar1), 125.5 (CH para Ar2), 121.6 (2CH ortho Ar2), $77.0(\mathrm{CH}, \mathrm{C}-4), 52.4(\mathrm{CH}, \mathrm{C}-5), 49.3(\mathrm{CH}, \mathrm{C}-1), 44.3\left(\mathrm{CH}_{2}\right.$, C-6), 38.8 (CH, C-2), $34.2\left(\mathrm{CH}_{2}, \mathrm{C}-8\right), 29.7\left(\mathrm{CH}_{2}, \mathrm{C}-3\right), 16.1\left(\mathrm{CH}_{2}, \mathrm{C}-7\right)$. HRMS calcd for $\mathrm{C}_{24} \mathrm{H}_{24} \mathrm{NaO}_{6} \mathrm{~S} 463.1191\left(\mathrm{M}+\mathrm{Na}^{+}\right)$, found 463.1183 .

\section{Synthesis of Ginsenol analogues}

Synthesis of $\left(3 \mathrm{a} S^{*}, 4 R^{*}, 7 \mathrm{a} S^{*}, 8 R^{*}\right)-3-p h e n y l s u l f o n y l-8-m o r p h o l i n e-4-y l-1,4,5,6,7,7 \mathrm{a}-$ hexahydro-1,4-ethaninden-3a-ol, (9)

To a solution of $5(146 \mathrm{mg}, 0.39 \mathrm{mmol})$ in dry THF $(5 \mathrm{~mL})$, a solution of $n$-BuLi $(1.6 \mathrm{M}$ in $n$ Hexane) $(0.49 \mathrm{~mL}, 0.78 \mathrm{mmol})$ is added at $-78^{\circ} \mathrm{C}$ under Argon After one hour, the starting material is not visible by TLC. The reaction is quenched with saturated aqueous solution of $\mathrm{NH}_{4} \mathrm{Cl}$ and the product is extracted with EtOAc. The combined organic layers are washed with brine, dried over $\mathrm{Na}_{2} \mathrm{SO}_{4}$, filtered, and concentrated. The resulting crude is purified by flash chromatography (silica gel, $n$-Hexane/ EtOAc 7/3 ) to yield 9 (72.5 mg, 50\%).

9. IR (film) v ( $\left.\mathrm{cm}^{-1}\right): 3489,3065,2949,2870,2807,1447,1304,1148,1115,1090,1034,980$, 907, 870, 756, 725, 689, ${ }^{1} \mathrm{H}-\mathrm{NMR} \delta(\mathrm{ppm})\left(400 \mathrm{MHz}, \mathrm{CDCl}_{3}\right): 7.55(2 \mathrm{H}, \mathrm{m}, \mathrm{Ar}), 7.55-7.26(3 \mathrm{H}$, 
m, Ar), 6.98 (1H, d, J=3.5 Hz, H-2), 3.75 (4H, m, H-3', H-5'), 2.70 (1H, m, H-1a), 2.50 (2H, br s, H-6' or H-2'), 2.39 (2H, br s, H-8, H-7a), 2.30 (2H, br s, H-6' or H-2'), 2.03 (2H, m, H-1b, H4), 1.87 (2H, m, H-5), 1.70 (1H, m, H-6), 1.65 (2H, m, H-7), 1.46 (2H, m, H-6, Ha-1), ${ }^{13} \mathrm{C}-\mathrm{NMR}$ $\delta(\mathrm{ppm})\left(100 \mathrm{MHz}, \mathrm{CDCl}_{3}\right): 150.7$ (C, C-3), 146.8 (CH, C-2), 142.5 (C, C-ipso Ar), $132.8(\mathrm{CH}$ para $\mathrm{Ar}$ ), 128.9 (2CH meta Ar), 127.5 (2CH ortho $\mathrm{Ar}), 79.1$ (C, C-3a), 67.0 (2 $\mathrm{CH}_{2}, \mathrm{C}-3$ ', C-5'), 65.4 (CH, C-8), 51.8 (2CH 2, C-2', C-6'), 49.6 (CH, C-4), 43.8 (CH, C-1a), 38.6 (CH, C-7a), 25.4 $\left(\mathrm{CH}_{2}, \mathrm{C}-1\right), 23.4\left(\mathrm{CH}_{2}, \mathrm{C}-5\right), 21.7\left(\mathrm{CH}_{2}, \mathrm{C}-7\right), 18.7\left(\mathrm{CH}_{2}, \mathrm{C}-6\right)$. HRMS calcd for $\mathrm{C}_{21} \mathrm{H}_{27} \mathrm{NNaO}_{4} \mathrm{~S}$ $412.1558\left(\mathrm{M}+\mathrm{Na}^{+}\right)$, found 412.1150 .

\section{Synthesis of $\left(1 \mathrm{a} S^{*}, 3 \mathrm{a} S^{*}, 4 R^{*}, 7 \mathrm{a} S^{*}, 8 S^{*}\right)-3$-phenylsulfonyl-3a-hydroxy-3a,4,5,6,7,7a-hexahydro-1aH- 1,4-ethaninden-8-yl phenyl carbonate, (10)}

To a solution of $8(33.7 \mathrm{mg}, 0.08 \mathrm{mmol})$ in dry THF $(2 \mathrm{~mL})$, a solution of $n$-BuLi (1.6M in $n$ Hexane) $(0.1 \mathrm{~mL}, 0.16 \mathrm{mmol})$ is added at $-78^{\circ} \mathrm{C}$ under Argon. The mixture is stirred under these conditions for one hour. The reaction is quenched with saturated aqueous solution of $\mathrm{NH}_{4} \mathrm{Cl}$ and the product is extracted with EtOAc. The combined organic layers are washed with brine, dried over $\mathrm{Na}_{2} \mathrm{SO}_{4}$, filtered, and concentrated. The resulting crude is purified by flash chromatography (silica gel, $n$-Hexane/ EtOAc 1/1) to yield 10 (16.9 mg, 50\%).

10. IR (film) v (cm $\left.{ }^{-1}\right): 3500,2850,1750,1545,1360,1300,1250,750,700 ;{ }^{1} \mathrm{H}-\mathrm{NMR} \delta$ (ppm) (400 MHz, $\left.\mathrm{CDCl}_{3}\right): 8.00$ (2H, m, Ar1), 7.60 (1H, m, Ar1), 7.50 (2H, m, Ar1), 7.35 (2H, m, Ar2), $7.25(1 \mathrm{H}, \mathrm{d}, J=3.6 \mathrm{~Hz}, \mathrm{H}-2), 7.20$ (1H, m, Ar2), $7.10(2 \mathrm{H}, \mathrm{m}, \mathrm{Ar} 2), 4.18$ (1H, d, J=9.3 Hz, H-8), 3.65 (2H, m, H-5), 2.85 (1H, br s, H-1a), 2.28 (1H, m, H-7a), $2.10(1 \mathrm{H}, b r s, \mathrm{H}-4), 1.80(1 \mathrm{H}, \mathrm{m}$, Ha-1), 1.25 (1H, m, Hb-1), 2.00-1.50 ( 4H, m, H-6, H-7), ${ }^{13} \mathrm{C}-\mathrm{NMR} \delta(\mathrm{ppm})\left(100 \mathrm{MHz}, \mathrm{CDCl}_{3}\right)$ : 154.0 (1C, C-2'), 151.3 (2C, C-3, C-ipso Ar2), 148.0 (CH, C-2), 140.0 (C, C-ipso Ar1), 133.4 (CH, CH para Ar1), 129.2 (2CH meta Ar1), 129.1 (2CH meta Ar2), 127.9 (2CH ortho Ar1), 125.2 (CH para Ar2), 121.8 (2CH ortho Ar2), 78.5 (C, C-3a), 56.3 (CH, C-8), 51.0 (CH, C-4), $44.8\left(\mathrm{CH}_{2}, \mathrm{C}-5\right), 43.0(\mathrm{CH}, \mathrm{C}-1 \mathrm{a}), 27.0(\mathrm{CH}, \mathrm{C}-7 \mathrm{a}), 29.6\left(\mathrm{CH}_{2}, \mathrm{C}-1\right), 21.6\left(\mathrm{CH}_{2}, \mathrm{C}-7\right), 18.2\left(\mathrm{CH}_{2}\right.$, C-6). HRMS calcd for $\mathrm{C}_{24} \mathrm{H}_{24} \mathrm{NaO}_{6} \mathrm{~S} 463.1191\left(\mathrm{M}+\mathrm{Na}^{+}\right)$, found 463.1185.

\section{Acknowledgements}

Financial support for this work came from F.S.E., Universidad de Salamanca and MICINN (CTQ2009-11172BQU), and Junta de Castilla y León (Spain) GR-178, (SA063A07). The authors thank also Dr. A. M. Lithgow xfor the NMR spectra and Dr. César Raposo for the mass spectra. J.P. and M.F.F. are grateful for their FPI doctoral fellowships to Junta de Castilla y León.

\section{References}

1. Iwabuchi, H.; Yoshikura, M.; Kamisako, W. Chem. Pharm. Bull. 1988, 36, 2447. 
2. Baillie, L. C.; Batsanov, A.; Bearder, J.R.; Withing, D. A. J. Chem. Soc., Perkin Trans I, 1998, 3471.

3. Collado, I. G.; Aleu, J.; Macías-Sánchez, A. J.; Hernández-Galán, R. J. Nat. Prod. 1994, 57, 738.

4. (a) Hanson, J. R. Pure Appl. Chem. 1981, 53, 115. (b) Coley-Smith, J. R.; Verhoeff, K.; Jarvis, W. R. Eds. The Biology of Botrytis, Academic Press: London, 1980. (c) Fraga, B. M.; González-Coloma, A.; Gutiérrez, C.; Terrero, D. J. Nat. Prod. 1997, 60, 880. (d) Nohara, T.; Kashiwada, Y.; Nishioka, I. Phytochemistry 1985, 24, 1849

5. (a) Diez, D.; Sanfeliciano, S. G.; Marcos, I. S.; Basabe, P.; Garrido, N. M.; Urones, J. G., Goodman, J. M.; Bastida, A. J. Synlett 1998, 1361. (b) Díez, D.; Sanfeliciano, S. G.; Marcos, I. S.; Basabe, P.; Garrido, N.M.; Urones, J. G. Synthesis 2001, 1069. (c) Diez, D.; Beneitez, M. T.; Marcos, I. S.; Garrido, N. M.; Basabe, P.; Urones, J. Synlett 2001, 655.

6. Díez, D.; Parra, M.; Sanfeliciano, S. G.; Marcos, I. S.; Garrido, N. M.; Basabe, P.; Jiménez, A.; Broughton, H. B.; Urones, J. G. Synthetic Commun. 2002, 32(12), 1829 and references cited therein. See too Butkus, E. Synlett 2001, 1827.

7. Iriepa, I. Arias, M. S.; Lorente, A.; Galvez, E.; Florencio, F. Sanz-Aparicio, J. J. Mol. Struct. 1989, 102(1-2), 15.

8. Caldararu, H.; Moraru, M. J. Am. Chem. Soc. 1974, 149.

9. Camps, P.; Iglesias, C. Tetrahedron Lett. 1985, 5463.

10. (a) Ravishankar, L.; Rele, D. N.; Geetha, K. V.; Mathur, H. H.; Trivedi, G. K. Magnetic Resonance in Chemistry 1987, 25, 960. See too: (b) Ravishankar, L.; Trivedi, G. K., Indian, J. Chemistry 1989, 28B, 303. (c) Butkus, E.; Stoncius, A. Synlett 1999, 234. (d) Hickmott, P. W.; Miles, G. J.; Sheppard, G.; Urbani, R.; Yoxall, C. T. J. Chem. Soc., Perkin Trans. 1973, 1515. (e) Hickmott, P. W.; Woodward, K. N.; Urbani, R. J. Chem. Soc. Perkin Trans I 1975, 1885. (f) Hickmott, P. W.; Cox, P.J.; Sim, G. A., J Chem. Soc. Perkin Trans I 1974, 2544. (g) Goverdhan, M.; Vishwakarma, S. Chem. Rev. 1999, 99, 881

11. Allan, R. D.; Cordiner, B. G.; Wells, R. J. Tetrahedron Lett. 1968, 58, 6055

12. (a) Hobson, J. D.; Mc.Cluskey, J. G. J. Chem. Soc. (C) 1967, 2015. (b) Fabris, F.; Lucchi, O. J. Org. Chem. 1997, 62, 7156. 